IZA DP No. 428

Mothers, Fathers and Children after Divorce: The Role of Institutions

Daniela Del Boca

February 2002 


\title{
Mothers, Fathers and Children after Divorce: The Role of Institutions
}

\author{
Daniela Del Boca \\ University of Turin and IZA, Bonn
}

Discussion Paper No. 428

February 2002

\author{
IZA \\ P.O. Box 7240 \\ D-53072 Bonn \\ Germany \\ Tel.: +49-228-3894-0 \\ Fax: +49-228-3894-210 \\ Email: iza@iza.org
}

This Discussion Paper is issued within the framework of IZA's research area Evaluation of Labor Market Policies and Projects. Any opinions expressed here are those of the author(s) and not those of the institute. Research disseminated by IZA may include views on policy, but the institute itself takes no institutional policy positions.

The Institute for the Study of Labor (IZA) in Bonn is a local and virtual international research center and a place of communication between science, politics and business. IZA is an independent, nonprofit limited liability company (Gesellschaft mit beschränkter Haftung) supported by the Deutsche Post AG. The center is associated with the University of Bonn and offers a stimulating research environment through its research networks, research support, and visitors and doctoral programs. IZA engages in (i) original and internationally competitive research in all fields of labor economics, (ii) development of policy concepts, and (iii) dissemination of research results and concepts to the interested public. The current research program deals with (1) mobility and flexibility of labor, (2) internationalization of labor markets, (3) the welfare state and labor markets, (4) labor markets in transition countries, (5) the future of labor, (6) evaluation of labor market policies and projects and (7) general labor economics.

IZA Discussion Papers often represent preliminary work and are circulated to encourage discussion. Citation of such a paper should account for its provisional character. A revised version may be available on the IZA website (www.iza.org) or directly from the author. 
IZA Discussion Paper No. 428

February 2002

\section{ABSTRACT \\ Mothers, Fathers and Children after Divorce: The Role of Institutions*}

In recent years the increase in the divorce rate in many advanced countries and the predominance of female-headed families among the poor has generated much interest in the relationship between divorce and the welfare of mothers and children. In this paper I will review a small body of economic literature which has been recently developed in order to analyze the economic consequence of divorce on the welfare of fathers, mothers and children under alternative behavioral assumptions. Important economic and econometric issues arise from an analysis of welfare in non intact households as compared with intact households. In particular the focus is on the role that institutions play in post-divorce arrangements and important implications concerning policies for child support, custody, and visitation.

JEL Classification: $\quad$ D10, K40

Keywords: Divorce, intra-household allocation, children welfare

Daniela Del Boca

Department of Economics

University of Turin

Via Po 53

10124 Torino

Italy

Tel.: +39-11-6702726

Fax: +39-11-6702762

E-Mail: daniela.delboca@unito.it

\footnotetext{
${ }^{*}$ Presidential Address of the Annual Congress of ESPE2000 held on June 15, 2000 in Bonn. I would like to thank Christopher Flinn and Rocio Ribero, Maristella Botticini and Silvia Pasqua for their helpful comments.
} 


\section{Introduction}

A major trend among families in the United States as well as other advanced countries, is the increase in marital instability. When parents separate, economic difficulties arise for a series of reasons. First, the costs of achieving any given living standard are higher for two households than for one. Second, the direct costs involved for lawyers, as well as house moving costs involved in a separation lowers resources available. Thirdly, the wage rate of the custodial parent (in most cases the mother) is lower than the wage of the non-custodian. Finally, and more importantly, the nonresidential parent (generally the father) contribute to their children less after separation.

Most research has focused on this last issue, which seems to be the most important factor of the loss of welfare for mothers and children after divorce. Statistical evidence shows that divorced fathers (even those who are better off) fail to support their children at the same level to which they were accustomed during marriage. In spite of child support laws and enforcement, the compliance rate with child support orders is still very low and a significant proportion of children entitled to child support receive nothing.

Until a few years ago this phenomenon has been predominantly studied by sociologists, psychologists and social workers. Only recently economists have analyzed the economic consequences of marital instability. The economic studies on the effect of living arrangements on children welfare has focused on many different aspects (Haveman and Wolfe 1994, Browning 1992). Most of the research has analyzed the consequence of family dissolution for children outcomes in terms of their educational attainment. Children and young adults who live in a single parent family complete less education than those who have always lived in an intact two parent family. The dissolution of a family typically lowers resources available for investments in children and their socio-economic attainments as adults. Other studies focus on the long term effect on the labor market outcomes, partnership dissolution, early childbearing, distress and smoking (Hernandez, Beller and Graham 1996, Ermisch and Francesconi 2001, Hill et al. 2001).

In this paper we consider children welfare in terms of financial contribution from the parents, direct expenditures and time spent with them (even if not in all studies they are directly observable).

The issue of the welfare decline of children after divorce is crucial especially in the US and the UK, where the number of children in poverty caused by divorce has grown more than elsewhere. In these countries more than in others after divorce a high proportion of children lose contact with non residential parents (because of higher mobility, smaller role of the extended family). Because of the growing importance of these phenomena, it seems fundamental to focus on 
how institutions can intervene to reduce the negative impact of divorce on children's welfare (in terms of available income and time with the parents).

A limited but interesting field of literature has been developed, combining elements of bargaining theory and microeconomic analysis. We intend to examine how economists have studied the role of institutions in divorced households, illustrating important methodological and empirical issues. In Section 2 we present descriptive evidence on divorce rates, child support and welfare conditions of divorce households in various countries, illustrating how the outcome of divorce can be different in contexts characterized by different institutions. In Section 3 we describe several methodological, theoretical and empirical differences between non-intact households and intact ones. One of the most important differences has to do with the fact that institutional agents intervene in non-intact households to compensate for the negative effects of divorce on children's welfare.

In Section 4 and 5 we describe and compare different approaches concerning decisionmaking methods used by parents and institutions in determining child support and visitations. In Section 6 we illustrate various methodological problems in analyzing survey response to questions concerning child support and visitations. We finally discuss the data we need in order to succeed in differentiating between the models considered and to establish which modeling strategy is the most appropriate for interpreting facts related to post-divorce relationships between parents and children. Section 7 contains some conclusive remarks.

\section{The Facts}

In the United States and Europe an increasing number of children are living with only one parent, most often with the mother. Divorce rates differ remarkably across countries but have risen everywhere since 1970 (Table 1). 
Table 1 Divorce rates in advanced countries

\begin{tabular}{|l|l|l|l|l|l|}
\hline Country & $\mathbf{1 9 6 0}$ & $\mathbf{1 9 7 0}$ & $\mathbf{1 9 8 0}$ & $\mathbf{1 9 9 0}$ & $\mathbf{2 0 0 0}$ \\
\hline US & 2.2 & 3.5 & 5.2 & 4.8 & 4.9 \\
\hline UK & 0.5 & 1.1 & 2.8 & 2.9 & 3.0 \\
\hline Sweden & 0.6 & 1.3 & 1.9 & 2.3 & 2.3 \\
\hline Germany & 1.0 & 1.3 & 1.9 & 2.3 & 2.3 \\
\hline France & 0.7 & 0.8 & 1.5 & 1.9 & 2.1 \\
\hline Italy & 0.2 & 0.2 & 0.3 & 0.5 & 0.7 \\
\hline
\end{tabular}

Source:OCDE Demographic yearbooks several years.

Especially in the US and the UK, where divorce increase more than elsewhere, single parents with minor children are the most economically vulnerable households (Jarvis and Jenkins 1997, Duncan and Hoffman 1988, Goode 1993, Bradshaw et al. 1997). Comparative data on child poverty rates across countries in each household type show that the two extreme cases are the US (where the child poverty rate is highest) and Sweden (where it is the lowest), even though the population share of the two subgroups is the same). In terms of differences between poverty rates between lone and two-parent households, the difference is highest in the US.

Table 2

Child Poverty by household type

\begin{tabular}{|l|l|l|l|l|}
\hline Country & \multicolumn{3}{l|l}{ Population shares } & Poverty rates \\
\hline & Lone & Two parents & Lone & Two-parents \\
\hline US & 15 & 60 & 59.6 & 16.7 \\
\hline UK & 19 & 75 & 40.3 & 17.5 \\
\hline Sweden & 15 & 82 & 4.5 & 3.6 \\
\hline Germany & 9.5 & 77 & 43.3 & 8.5 \\
\hline France & 7.2 & 75 & 25.4 & 7.7 \\
\hline Italy & 2.0 & 73 & 20.2 & 20.9 \\
\hline
\end{tabular}

Source: OECD 1999 
These differences depend on several institutional characteristics related to the labor market and to the service sector, as well as to child support systems likely to help alleviate the negative impact on child welfare.In countries where divorce rates are particularly low (e.g. the result of religious influence), divorce is still concentrated among higher income couples and post-divorce parents often rely on their relationship with the extended family (such as in Southern European countries).

In terms of labor market characteristics, in countries where part-time work or flexible arrangements are available, divorced women with childcare responsibilities are more likely to work. (such as in Northern Europe). In households where mothers are employed the negative impact of divorce is lessened (Jannti and Danziger 1994, Del Boca and Ribero 1998). A comparison of the composition of total income of single parents households in various countries shows that in US and UK the share of public transfer is greater than the labour income.

\section{Tab. 3 -Income Composition in Single Parents Households}

\begin{tabular}{lcc}
\hline Countries & Labour income & PublicTransfer \\
US & 0.48 & 0.52 \\
UK & 0.25 & 0.75 \\
Sweden & 0.57 & 0.43 \\
Germany & 0.71 & 0.29 \\
France & 0.49 & 0.51 \\
Italy & 0.78 & 0.22 \\
\hline
\end{tabular}

Source: OECD 1999

Finally also the characteristics of child support systems vary across countries in the way they assign jurisdiction and responsibility. The courts have a primary role in determining support obligations in the UK and US; this reflects their historical role in divorce and separation: While in the US and UK the courts used to play a role because non-marital birth was considered a crime, in other European countries, on the other hand, their role is residual and they often only ratify preliminary voluntary agreements between parents.In Northern European countries the general trend has been toward the development of rules, or at least guidelines, which are believed to result in greater transparency of the process, encouraging understanding and parental compliance, consistency and equality in treatment and ease of administration (Corden 1999). In the US there was a shift from discretionary decision-making to rules-based schemes from the Family Support Act of 1988. The goals were to establish child support awards for all children with absent parents 
and improve the adequacy and horizontal equity of these awards, increasing the uniformity of awards for families with similar characteristics and increasing compliance (Williams 1994).

Nevertheless, the US awards still vary across states as each is free to choose the amount of the awards required and the guidelines selected. Only recently some states have been able to withhold child support from wages when a non-resident parent becomes delinquent (withholding in response) and to use proportional child support instead of a fixed amount in order to make the transfer adequate to inflation and changes in income. Recent research has shown that the presence of guidelines has increased the probability of receiving a child support award and has increased the size of the awards. While in the US the focus is on parental responsibility and work incentives, in Nordic countries there has been a traditional commitment to advance maintenance schemes (state support for the children when parents do not comply). As a result, Nordic countries achieve the highest level of compliance with payments of child support (and the lowest children poverty rates), while in the US the compliance rate is still very low.

These differences illustrate how institutions play an important role in alleviating the negative impact of divorce on child welfare. Given these considerations, we focus mainly on the US case and illustrate several ways in which the institutional agents intervene in determining postdivorce arrangements and the resulting outcomes. While several legal studies have analyzed the behavior of judges in deciding child support and custody arrangements (Williams 1994, Yee 1979, White and Stone 1976), only recently have economists included institutional agents in their analyses of non-intact households and have explicitly modeled their behavior and the outcomes of their strategies.

\section{Behavior in Intact and Non-intact Households}

In comparison with the situation prevailing in intact households, there are several differences in non-intact households. In this section we illustrate and discuss what we see as those which are most relevant. We assume that each parent has a utility function defined with respect to his/her own private consumption, his/her spouse's and child "quality" (produced by expenditures on child goods by the parents and their time inputs).

The first difference we consider in our analysis concerns parents' preferences concerning their partner's and children's welfare when marriage dissolves. As we state above, married parents' 
utility functions are defined over their own consumption, the quality of their children and the other parent's consumption. The inclusion of the other parent's consumption represents the presence of altruism which is normally thought to exist in intact households. After the dissolution of marriage, altruistic feelings between parents usually disappear and the utility function of one parent does not include the other parent's consumption: the welfare of the other parent may even become a "bad" rather than a "good."

The parents' valuation of the children's welfare may change after divorce. With the dissolution of households, even if the children's welfare remains a public good, children's time becomes a private good. A number of the models discussed below can be set in the following general framework. The utility function of each parent is defined over his/her consumption, the child's consumption, and the time that the parent spends with the child,

$$
U_{i}=U_{i}\left(c_{i}, k, \tau_{i}\right) \quad i=m, f
$$

All three goods are assumed to be normal. When the parents are married, time with the child is a public good in the sense that it is nonexcludable. Normalizing total available time with the child to 1 , each parent's utility while married is given by $U_{i}\left(c_{i}, k, 1\right)$. When parents are divorced, since the parents no longer inhabit the same household, time with the child becomes a private good and must be allocated so that $\tau_{m+} \tau_{f}=1$. Then given the allocation of time with the child in the divorce state, the utility of divorced parent $i$ is given by $U_{i}\left(c_{i}, k, \tau_{i}\right)$. Due to the fact that time spent with the child is a normal good, we know that

$$
U_{i}\left(c_{i}, k, 1\right) \geq U_{i}\left(c_{i}, k, \tau_{i}\right) \text { for } 1 \geq \tau_{i} .
$$

The implications of this particular form of scale diseconomy for expenditures on the child depend on the features of the utility function specification. Most commonly it is assumed that the utility yield from a given level of expenditures on the child to a divorced parent is proportion to the time spent with the child. An immediate result of such an assumption is that the incentive to spend on the child under divorced is less for both parents than it is when they are married. Formally, this is expressed as follows. In equilibrium (which ever equilibrium concept is employed), the determination of total child expenditures is given by the function

$$
k=k\left(y_{m}, y_{f}, \tau_{m}, \tau_{f}\right) .
$$

Then we have

$$
k\left(y_{m}, y_{f}, t_{m}, t_{f}\right) \leq k\left(y_{m}, y_{f}, 1,1\right) \text { for } \tau_{m+} \tau_{f}=1
$$

Institutional agents presumably may try to mitigate the reduction in expenditures on the child that can be expected to occur naturally as a result of this particular form of scale diseconomy by 
shifting the balance of the time spent with the child as well as total household income toward the parent presumed to weight the child's welfare most highly.

Another important difference concerns resource allocation. When households separate, resource constraints are altered and certain scale economies may be lost. It is more expensive to have two houses instead of one, in terms of fixed costs (such as housing and utilities) and costs associated with the need to have two sets of clothes and school books for the children, as well as toys and furniture in case of joint custody arrangements (Weiss 1984). The calculation of postdivorce child costs that should be the basis of child support orders have to take into account the fact that if the children spend time in both households (such as in joint custody arrangements) more direct expenditures are to be made by the resident parent, therefore orders should be lower [see Lazear and Michael 1988, Del Boca and Ribero 1998].

The method by which decisions concerning the public good are made may also be different. In intact households, we may expect cooperation between the spouses, which means that publicgood decisions [such as investment in child quality] lie on the Pareto frontier. In non-intact households the default mode of behavior may be non-cooperative if for no other reason than for an increase in coordination and implementation problems. In general, however, there is no reason a priori not to assume cooperation in intact households and non-cooperation in non intact ones.

In Del Boca and Flinn (1995) we assume non-cooperation, which implies lower expenditure on child quality in cases of divorce [without changing preferences or incomes]. If there is cooperation, on the other hand, changes in expenditures on children after divorce can only come about through changes in preferences or resource constraints [for example, through loss of economies of scale]. A discussion of the methods by which decisions are made in divorced households is in Del Boca and Flinn 1994.

Another important difference concerns the ability to distinguish between resources. In intact households, resources are generally treated as indistinguishable and it is natural to assume that expenditures by the parents are more-or-less perfect substitutes for one another. Analyses that attempt to distinguish between them in order to analyze how resources are allocated to various items, in order to identify the expenditures for the children so as to measure children's costs, have made assumptions regarding "the sharing rule" (Chiappori 1992). Recent research analyzing intact households have shown that husbands and wives choose expenditures on children differently and that their income has different effects on the allocation of family resources (Schultz 1990, Del Boca 1998). When marriage dissolves and parents live in separate households, these differences may become more important. 
In non-intact households, resources are distinct and allow separate analyses to be made. The fact that we observe child support, and in some cases direct expenditure by one parent on the child, means that the analysis of the cost of children is less problematic than in intact households. Most surveys usually follow only the parent who has custody of the children, but retain information from transfers and sometimes also direct expenditures on the children by the non-resident parent. For the divorced parents there are incentives to misreport information concerning their income and contribution to the children. For the non-residential there are incentives to hide income in order to pay less child support and to misrepresent the financial contribution for fear of legal punishment. After marital dissolution the issue of non-response bias affects the measurement of incomes, transfers, and time spent with the children reported by each parent. These measurement problems are analyzed in Ribero (1994), who compares the non-reporting behaviors of custodial and noncustodial parents.

Finally, societal agents play virtually no role in determining the welfare distribution within intact households, except in extreme circumstances such as cases of child neglect. In contrast, societal institutions do intervene at least indirectly in decisions made by divorced parents concerning the allocation of inter-household resources. Institutional intervention is due mainly to concerns about the deleterious effects of the child's partial separation on each parents' motivation to spend resources (time and income) on the child. Institutions may constrain and mediate the interaction between divorced parents, using the terms and enforcement of legally stipulated divorce agreements as their principle instruments of intervention in so far as they relate to custody arrangements and wealth and income transfers between the ex-spouses (Mnookin and Kornhauser (1979), Weitzman (1985), Mnookin 1990).

Reasons for this difference in institutional behavior are quite evident. With cooperation, altruism and vicinity, and with the parents having private information that the state lacks, the state cannot improve on the Pareto efficient outcomes assumed to be generated by the family. In nonintact households without cooperation or altruism, state intervention in the distribution of resources across agents [child support transfers ordered, the allocation to the parents of time with the child] serves to compensate certain members of the non-intact households for their change in state. This may therefore be the most relevant difference between intact and non-intact households that can be observed. Only in non-intact households where institutions intervene can we observe their actions and their results in terms of parents' response and children welfare (Sunstein 1986, Mnookin and Weinberg 1988).

Several papers have empirically considered the role of institutions such as the state in formulating laws and guidelines on courts and parents' behavior after divorce. The role of on child 
support awards has been analyzed by various authors. Beller and Graham (1993) find that the presence of child support guidelines reduce award rates. Pearson et Thoennes. (1988) find that award levels as a percentage of father's income are significantly higher after the enactment of guidelines in the states considered. Other studies focus on the effect of mandatory child support and the percentage of child support on compliance and on the amount due (Del Boca 1996).

This literature however have not explicitly modeled the role of the institution and have considered variations in laws or guidelines as exogenous events. In the next sections we will analyze some of these issues in a framework that focuses on the behavior of the institutions involved in divorce and the impact of their decisions on parents' and children's welfare.

\section{The Role of Institutions}

Besides the parents and the children, another important agent is involved in the post-divorce negotiation process: the legal and social system. Institutional agents define the rules under which outcomes are determined and more importantly have implicit and explicit evaluations of those outcomes. Until recently only legal scientists have analyzed the role of the institutions in postdivorce arrangements. Mnookin and Kornhauser (1979) and Cooter et al. (1982) examine the role of legal institutions in determining final divorce orders through the differential bargaining power given to the contestants. Elster (1989) have examined the extent to which legal institutions can use rational decisions rules in adjudicating custody cases. Williams (1994) and Yee (1979) have analyzed the factors affecting the variability of judges' decisions in different states and different cases. Economists have only recently attempted to study institutional decision-making in dividing the resources when households break up.

Institutions have a fundamental role at the time of the separation in dividing any assets and dividing children's time between the parents. Given child quality at the time of the separation, each parent would like more time with the child since utility is increasing in this argument. In this sense, children are not very different from other jointly-owned financial assets. However, once financial assets are divided, institutional agents have little interest in what happens to them. This is not the case with children. Children are agents and institutional agents are responsible for protecting their welfare (Maccoby and Mnookin 1992).

The division of time between the parents partially determines the utility level of the children. The institutional agent can intervene in establishing the custody arrangements and the number of visits allowed by arrangements. Custody is distinguished between physical and legal. In 
terms of economics, physical custody is what has primarily been referred to the quality production function of children. Legal custody can principally be seen as affecting the manner in which decisions are made. Another important aspect of the division of time is the number of visits allowed to the parent who does not live with the children.

Since most custody arrangements specify that the majority of the child's time is to be spent with the mother, income transfers from the father to the mother are often ordered because of income disparities between parents. Decision-making by the institutional agent is therefore an important element in establishing child support as well as for specifying the endowment of time with the child for each parent.

Child support order adds another policy variable to the institutional agent's instruments to attain some desirable outcome in line with their assessment of justice. Without the ability to order transfers, the "best interests of the child" - in terms of maximization of child quality - would too often lead to the agent with the largest financial resources getting the largest share of the child's time. The institutional agents must also deal with compliance by the parent ordered to pay, but also in terms of custody - which is more difficult to monitor.

Following these lines of discussion, we survey several models that study the role of the institutional agent in determining the time the children are to spend with the two parents and the contribution that each parent has to devote to the children. Institutions are examined in the theoretical and empirical analysis of divorce settlements by Weiss and Willis (1985, 1993). In their research into post-divorce cases, the child continues to be a public good as it was during marriage, with changes in the manner in which expenditure decisions are made. In their first paper, the primary role of the institutional agent was to enforce divorce settlements, while in the second, more focus was placed on the role of settling disputed cases when the mother and father could not come to an amicable agreement.

In Del Boca and Flinn (1995) the focus is on parental choices regarding compliance with child support orders and the effects of divorce settlements on expenditure for children. Institutional agents are assumed to maximize their own objective function which takes into account also the impact of their decisions on the child support payments of the father and the mother's expenditures on the child. In Flinn (2000), parents are allowed to choose between non-cooperative and cooperative behavior. The impediment to behaving cooperatively is disagreement between the parents as to how to divide the cooperative surplus. The institutional agent here has the role of encouraging the parents to adopt cooperative behavior which would also enhance the welfare of the children. In Del Boca and Ribero $(1999,2001)$, an attempt is made to include time in the analysis of post-divorce welfare of parents and children; here the institutions determine the initial 
endowments of time with the child of each parent. Utilizing these models, in which the institutional agent has an explicit role and preferences, enables us to understand how changes in the environment affect the nature of institutional interventions and the welfare of mothers, fathers, children and the institutional actors.

\section{Child Support Orders and Compliance.}

The two most important reasons for the income loss of mothers and children after divorce are the fact that compliance with child support orders is far from perfect, and the average levels of child support awards are too low and inadequate. On the one hand, the non-custodial parent does not comply with what is owed to his or her children, while on the other hand the legal system determines a child support order that is inadequate to the children's needs. Empirical evidence and interpretation of the features of the two facts phenomenon are reported in Garfinkel and Oellerich 1989, Garfinkel and Melli 1990, Beller and Graham 1993), among others.

Both aspects require the analysis of the behavior of the institutional agent who sets the child support award and, in various ways, enforces compliance with the child support orders.

\section{The institution as guarantor of the contract (Weiss and Willis 1985, 1993)}

Weiss and Willis (1985) were the first to provide a theoretical interpretation of low compliance with the child support order. The father's non-compliance with the child support order is caused by his lack of monitoring power over the allocation of the transfer by the mother. The mother is usually chosen as the custodian who determines the expenditure on the public good (children). In their view, a father who wants to support his child, but not his ex-spouse, would tend to pay less than the amount he would like to spend on his child, since he cannot guarantee that the money will be spent on the child.

Weiss and Willis (1993) in a subsequent paper compare expenditure decisions in the Stackelberg model and in the Cournot model. In the former, only the custodian can spend money on the children, while in the second both parents can transfer directly to their children (for example, in the case of college education or in case of physical joint custody). According to their framework, inefficiency in the allocation of family resources in the case of divorce is common to both models. In the first case, the mother does not take into account the impact of her choices on the welfare of the ex-husband and uses part of the transfer for her own consumption. As a consequence, the father 
reduces his transfer with a negative impact on his children's welfare. In the second case, both parents pay less than the amount due with the intention of shifting the responsibility onto the other.

Intervention by the court is required to maintain efficiency in the allocation of family resources. While legal intervention can affect the bargaining power of the ex-spouses, the ultimate effect is a substantial reduction in economic welfare. Legal courts while are able to internalize some aspects of ex-ante contracting insurance for unanticipated changes in incomes and investments during marriage, cannot prevent ex-post inefficiencies caused by a lack of monitoring of the custodial allocation of resources.

They estimate that, in comparison with the needs of children, husbands underpay their exwives by about $50 \%$. As a result of the inefficiency caused by lack of control over the allocation of expenditure by the wives, child expenditure by divorcees are only about $40-70 \%$ of the efficient level. According to their estimates, the transfers would be larger if ex-ante contracts were enforced; but legal intervention however is not able to resolve the inefficiency due to the costs of monitoring. The shift towards non-fault divorce laws had a positive effect on divorced women by increasing child support transfers.

In their analyses, there is an ex-ante contract between the parents which include child support provisions, while the institutional agents are only involved in the enforcement process, but are not formally introduced into their theoretical model.

\section{The institution as a separate player (Del Boca Flinn, 1995).}

Other studies have explicitly considered the role of institutions, also considering the problem of non-compliance and enforcement. In Del Boca and Flinn (1995) and Flinn (2000), the objective of the analysis of child support orders and transfers is to examine both compliance with child support orders and the nature of the orders for the purpose of determining their cumulative effects on expenditures on the child. The difficulty in determining child support and orders derives from the fact that are involved several agents with different objectives, different resources and information sets .

The model we describe here has the objective of identifying important features of the distribution of the ratio of child support payments to child support orders, which shows two spikes at zero and 1 (at no compliance and perfect compliance). While no compliance and perfect compliance are the predominant features of the distribution, about 25 per cent of the sample makes a positive monthly payment that is not equal to the order amount, 14 per cent makes a transfer that is less than what is stipulated, whereas 11 per cent pay more than the ordered amount. Figure 1 shows the distribution of compliance (child support payment/order). 


\section{Figure 1 Distribution of Child support compliance}

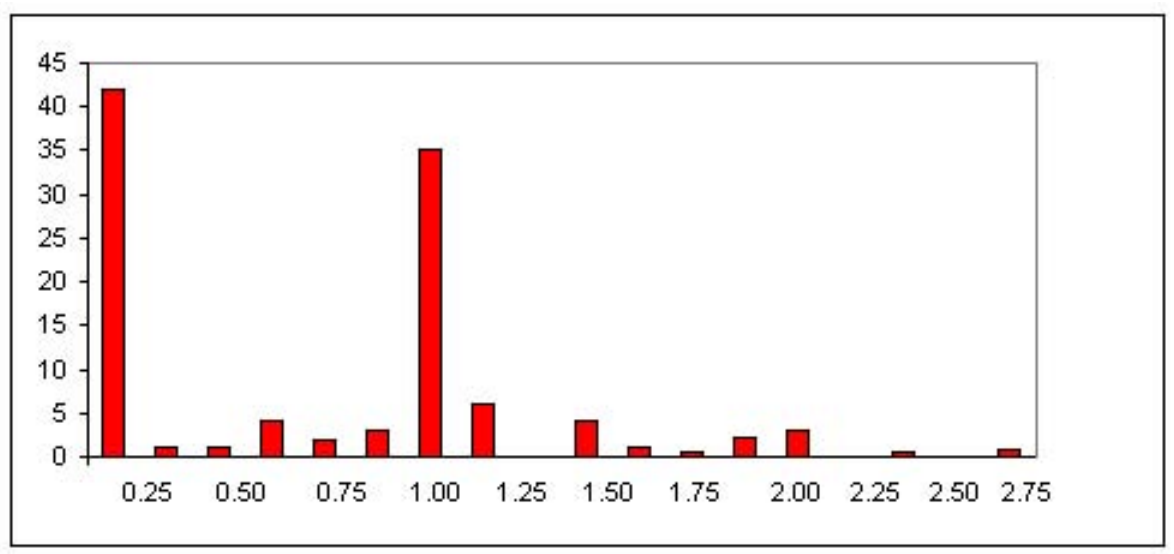

Source: Wisconsin Court Data see Del Boca Flinn 1995

The model we describe below is able to capture the qualitative features of the distribution . To examine the effect of child support orders and transfers on the welfare levels of all those involved, it is necessary to take into account the characteristics of all agents. It is assumed that i) divorced parents behave in a non-cooperative manner; ii) their preferences are defined by their own consumption and that of the child (Cobb Douglas); and iii) consumption by the child continues to be a public good just as it was during the marriage. Since mothers have full custody of the children, only they can make expenditure for the children. This leads to the predictions that we would be able to observe positive transfers from fathers to mothers even in the absence of child support awards.

The father's preferences are defined in terms of his own consumption $c_{f}$, his child's consumption $(k)$, and the cost of non-compliance with child support order.

$$
U_{f}=\delta_{f} \log \left(c_{f}\right)+\left(1-\delta_{f}\right) \log (k)-\theta \chi(t<s)
$$

Where $\chi[A]$ is the indicator function that takes the value 1 when $\mathrm{A}$ is true and 0 otherwise. $t$ is the child support transfer and $s$ is the child support order. The mother's utility is simply

$$
U_{m}=\delta_{m} \log \left(c_{m}\right)+\left(1-\delta_{m}\right) \log (k)
$$

$\delta_{m}$ and $\delta_{\mathrm{f} .}$ are the parents' preference parameters. The institutional agent takes the equilibrium responses of the parents into account when determining the child support orders (so the model has a 
Stackelberg structure). The institutional agent's preferences are represented by a linear function of the expected welfare of children, mothers and fathers:

$W(s, y, w)=\tau_{m} V_{m}(s, y, ?)+\tau_{k} V_{k}(s, y, ?)+\tau_{f} V_{f}(s, y, ?)$

where $s$ is the order, $y$ is the income and ? is a random variable representing the vectors of parents characteristics and costs of compliance, and $t$ are the welfare weights attached to each member of the family (which sum to 1). The child support awards are solutions to the institutional agent's first order condition associated with his or her utility-maximization problem. Using the first order conditions, preference weights are determined after specifying the institutional agent's expectations about parental post-divorce behavior.

The estimates of the preferences of the institutional agents (using the Wisconsin Court data) show that, consistently with the oft-heard claim, non-custodial fathers are given preferential treatment by courts and legislative agents. Child support orders are low not only because compliance becomes less likely as the order increases but also because of the relatively low valuation of the expected welfare of custodial mothers and children by institutional agents. The model can be used for addressing many policy-relevant issues.

An initial question is related to the effect of guidelines which are equitable and more favorable to mothers and children: what is the distribution of child support awards if institutional agents set the awards so as to maximize the expected welfare of children and custodial mothers? Comparative statistics show that if judges placed greater weight on the welfare of custodial parents, child support orders would be almost three times as much. Whereas the average award is 225 dollars per month in the sample, the average award when custodial mothers are given preferential treatment is 682 dollars.

Another important question: what is the effect of an increase in the penalty associated with non-compliance? If the penalty for not complying with child support order $(t<s)$ is raised, expected transfers get larger and the custodial parents and children experience an increase in their welfare. However, the order also changes: when non compliance costs increase for the father, the order decreases for the majority of sample cases. Since the judges give a substantial weight to father's welfare, the institutional agents reduce the order, offsetting the increase in expected transfers. The institutional agent thus has an important role in maintaining the status quo with regard to the distribution of welfare. 


\section{The institution as facilitator (Flinn, 2000).}

It is common for laypersons, and even social scientists, to say that non-custodial parents who meet their legally-mandated child support obligations are behaving "cooperatively," even though the term "cooperative behavior" typically has a very different connotation in the game theory literature. The paper by Flinn (2000) develops and estimates a model in which parents decide whether or not to cooperate. In his formulation, institutional agents are necessary for cooperative behavior to take place (but not sufficient). In this model institutional agents have no enforcement power, but instead play a potentially important role as arbitrators. Their child support orders are interpreted as suggestions of a possible division of the surplus arising from cooperation and serve as a coordination device when these suggestions are implementable.

The framework of his model is similar to that of Del Boca and Flinn (1995), which was described above. In terms of the implementation of the model, he also assumes Cobb-Douglas preferences for both parents, but does away with the assumption that non-custodial parents pay a (random) cost if they do not comply with the child support order. By ignoring non-compliance costs, we know that if parental behavior is non-cooperative, then the child support order $s$ will have no effect on the child support transfer $t$. Therefore, for $t$ to have an impact on $s$ we must expand the choice set of the divorced parents to include behavioral modes other than non-cooperation. The parents have to choose whether to behave cooperatively or non-cooperatively.

As in Weiss and Willis (1985) and Del Boca and Flinn (1995), the child is considered a public good, and the parents essentially play a form of voluntary contributions game.

While the non-custodial parent cannot directly purchase "child goods", in Del Boca and Flinn (1995) and Flinn (2000), their transfers to the custodial parent are only intended to increase the expenditures on the child. Thus the settlement still has the characteristics of a voluntary contributions game. As is always the case, when the parents ignore the positive impact of their own expenditure on the public good (the child) and behave non-cooperatively, then there will be underinvestment in the child. Cooperative outcomes, on the other hand, are efficient and produce utility payoffs to both parents that lie along the Pareto frontier. From an efficiency perspective, cooperative outcomes always dominate non-cooperative ones. This is particularly the case here, since the "public good" itself is endowed with a set of preferences. Since children can be assumed to prefer that more be spent on them rather than less, cooperative outcomes produce higher utility levels both for the divorced parents and also for their child. It seems clear that institutional agents concerned with the welfare of divorced parents and, especially, their children, should try to 
structure an environment in which divorced parents find it in their own interests to behave cooperatively.

Unfortunately, in practice there are a number of problems with the implementation of cooperative solutions. There is the issue of "cheating," since each parent has an incentive to deviate from the cooperative solution if they expect the other parent to adhere to it. Even abstracting from this issue, there remains the problem of dividing the "rents" that accrue to cooperation. This is a point typically ignored in cooperative game-theory literature, but is an especially important feature when considering the interaction between two parents who may exhibit some degree of antagonism toward one another. The problem is the following: judged solely by efficiency criteria, there are (in general) a continuum of equilibrium solutions to the expenditure problem faced by the parents. While each parent will be better off under any of the cooperative equilibria, each parent will have a different preference ordering for the solutions. How can they resolve this rent division problem? The institutional agent attempts to solve this problem for the parents.

Within this model, the institutional agent has no direct power or authority over the parents. Paradoxically, it is the absence of direct power that gives the agent her power to influence the welfare of members of the non-intact family. If each parent believes that the institutional agent has no bias in favor of the other, then the parents can agree to use them as a coordination device. An institutional agent observes the incomes of the divorced parents, but not their preferences (this lack of information makes it credible that the institutional agent's actions are unbiased). Using some unspecified, but "unbiased" mechanism, the institutional agent suggests a child support payment of $S$.

The Pareto frontier that contains all the cooperative equilibria of the model in the utility space implicitly defines a set of functional relationships between child support transfers $t$ and efficient expenditures (by the custodial parent) on the child $k$, denoted by $k(s)$. The smallest child support amount on this frontier is $\underline{s}$; the largest is $\bar{s}$; if the order $s$ suggested by the institutional agent is such that $\underline{s} \leq s \leq \bar{s}$, then the parents behave cooperatively, and if not, they revert to the default mode of non-cooperative behavior. If the parents do behave cooperatively, the transfer level is $t=s$ and the amount the mother spends on the child is given by $k(t)$. The parents only act cooperatively if $t=s$; in particular, when $t>s$, parental behavior is non-cooperative. In such a case, the transfer amount suggested by the institutional agent is too little (given the unknown preferences of the parents) and is not associated with any feasible cooperative outcome. It is in this sense that "exact" compliance is associated with cooperation, while non-compliance (which includes transferring more than the order) implies that the parents are behaving non-cooperatively. 
The model is estimated using the same data set as was used in Del Boca and Flinn (1995). Parameters characterizing the institutional agent's preferences are not identified, and in some sense must deliberately be left vague in consideration of their role as an unbiased "coordinator." Thus the only unknown parameters of the model are those characterizing the distribution of parental preferences. Given maximum likelihood estimates of these preferences, the following policy experiment is considered. Instead of assuming that institutional agents have no enforcement power in implementing their recommendations $s$, let them have absolute enforcement power. That is, assume that the order $s$ results in an income transfer of $s$ from the non-custodial parent to the custodial parent. What is the result of such a change in the role of the institutional agent on the expected expenditures on the child?

The net effect over the entire sample is essentially zero; in some sample cases, expected expenditures on the child decline considerably under perfect enforcement. The reason is that when transfers are guaranteed to be enforced by the state, the custodial agent (in this sample, always the mother) has no incentive to engage in cooperative behavior so as to induce the father to make the transfer to her. This results in lower expenditure on the child for a large set of possible values of parental preferences, thereby lowering expected expenditures. Therefore, there is a cost in perfecting enforcement, which is the lack of opportunity to lead parents towards cooperative behavior. This role of institutional agents as mediators or coordinators is typically not featured in debates on child support policy.

\section{Time Endowments and Post-divorce Welfare}

The division of children's time between the parents is the crucial issue of the post-divorce relationship between parents and children. After divorce, most parents want to continue to spend time with their children. Time spent with the children has direct and indirect impact on children's welfare: parents who maintain close contact with their children after divorce have more time to enjoy with them and more ways to monitor the effect of their transfers on their child's well-being (over 70 percent of parents with higher than average visitation rates have higher than average transfers as well as direct expenditures) (Del Boca and Ribero 1999). Table 4 reports the average child support orders, transfers, compliance and direct expenditures for children who receive visits once a week twice a month, during vacation or never from the non custodial parent. The amount of transfer paid to the children is higher in cases of frequent visitations, while the order is higher for parents who see their children unfrequently. Compliance rate is higher for parents who see their 
children often as well as the proportion of parents who spend directly on the children. These data seem to indicate that is a correlation between compliance, visitation and expenditures for the children. A higher proportion of non custodians who do not visit the children are remarried; the loss of contact is probably due to the competing demand of the current household. ${ }^{i}$

Table 4 Visitations, Child support Compliance and Expenditures on the child.

\begin{tabular}{|l|l|l|l|l|}
\hline & $\begin{array}{l}\text { Visits once a } \\
\text { week }\end{array}$ & Twice a month & $\begin{array}{l}\text { Visits during } \\
\text { vacation }\end{array}$ & No visitations \\
\hline Transfer & $247.3(396.6)$ & $218.5(363.1)$ & $144.6(150.4)$ & $9.26(48.11)$ \\
\hline Order & $248.1(430.5)$ & $269.5(441.9)$ & $281.7(316.5)$ & $87.9(201.7)$ \\
\hline Compliance & 0.83 & 0.77 & 0.66 & 0.10 \\
\hline $\begin{array}{l}\text { Non custodian } \\
\text { remarried }\end{array}$ & 0.61 & 0.76 & 0.76 & 0.85 \\
\hline $\begin{array}{l}\text { N. C. Spend } \\
\text { directly (\%) }\end{array}$ & 0.77 & 0.65 & 0.45 & 0.11 \\
\hline
\end{tabular}

Source: NLS72-5FU.

Little economic research has been carried out on the relationship between monetary transfers between parents and the division of the child's time. Here we present an attempt to include time in the post-divorce analysis of children's welfare (Del Boca and Ribero 1999). Time with children and transfers are crucial issues in post-divorce negotiation. A mother may object to her children visiting their father if she does not receive child support transfers, while the father may refuse to pay child support if he cannot see his children. Institutional agents, such as judges, state legislatures, etc., can impact the welfare of the members of non-intact families by altering the endowments for each of the parents.

The mother is viewed as being given the endowment of all of the child's time. Fathers typically begin with a substantial income endowment advantage over mothers, even if we view their incomes after mandatory transfers (order by the courts) have been made. There are generally gains from trade, with the mother exchanging the good with which she is heavily endowed, the child's time, for income to use for consumption. Given the distribution of the endowments, our model implies a positive relationship between transfers and visitation time.

Since it is typically the case that divorced fathers have higher income "endowments" than mothers, the assignment of the child's time to the mother is a way of balancing the market. Given their initial endowments, the parents engage in mutually beneficial exchange of the child's time for 
consumption. The determination of the amount of time spent with each of the parents is often a difficult and contentious issue in reality, and for many of the same reasons is quite a complicated phenomenon to model as well. In the model summarized here, each set of divorced parents constitutes a bilateral market in the preferences and endowments of each side, in conjunction with the constraint that the sum of the time the child spends with each parent must add up to a constant. In this way the implicit price of the child's time and the transfers between the parents of time and money are determined.

\section{The Institution as endowment setter (Del Boca and Ribero 1999, 2001).}

Following along the lines of Del Boca and Flinn (1995), it is assumed that the behavior of the parents is non-cooperative: each of them derives their own demand from utility maximization subject only to their budget constraint. Differently from Del Boca and Flinn (1995) and Flinn (2000), we assume that each parent can spend money on the children. The preferences are defined over a representative consumption good $\left(c_{m}, c_{f}\right)$ the amount of time they spend with their child $\left(h_{f}, h_{m}\right)$ and the direct expenditures on the children $\left(k_{f}, k_{m}\right)$. The mother's initial endowment is given by total time with the child $(\varepsilon)$. On the other hand, the father's initial endowment is given by his monetary resources.

The utility function are given by:

$$
\begin{aligned}
& u_{m}\left(c_{m}, h_{m}, k_{m}\right)=\delta_{1 m} \log \left(c_{m}\right)+\left(\delta_{2 m}\right) \log \left(h_{m}\right)+\left(\delta_{3 m}\right) \log \left(k_{m}\right) \\
& u_{f}\left(c_{f}, h_{f}, k_{f}\right)=\delta_{l f} \log \left(c_{f}\right)+\left(\delta_{2 f}\right) \log \left(h_{f}\right)+\left(\delta_{3 f}\right) \log \left(k_{f}\right)
\end{aligned}
$$

with $\sum \delta_{i=1}=\delta_{i m} \in(0,1), \delta_{i f} \in(0,1), \quad i \in\{1,2,3\}$,

It can be shown that, according to the model, fathers with higher incomes transfer more and visit more, while the mother's income has an ambiguous effect on child support transfers, and mothers with higher incomes allow fewer visits. The comparative statistics results help to understand the changes in transfers and visits that may occur in different situations.

Using the values for the parental preference parameters, empirical implementation can be used to solve for the equilibrium levels of visits and transfers, conditional on the model parameters, 
the preference parameters $\left(\delta_{m}, \delta_{f}\right)$, fathers' and mothers' income $\left(y_{m} ., y_{f}\right)$, and the initial endowment of time ( $\varepsilon$ ). Given the value of the preference parameters we can solve for $t, v, k_{f}, k_{m}$

$$
\begin{aligned}
& t\left(\delta_{m}, \delta_{f}, y_{m}, y_{f}, \varepsilon\right) \\
& v\left(\delta_{f}, y_{f}, \varepsilon\right) \\
& k_{f}\left(y_{m .,} y_{f}, \varepsilon\right) \\
& k_{m}\left(y_{m .,}, y_{f}, \varepsilon\right)
\end{aligned}
$$

Alternatively, given values of $t, v, k_{f}, k_{m}$ and the endowment $\varepsilon$, these equations can be inverted to solve for the implied preference parameters assuming endowment equal to the average found in the sample, (that is, the father has child once a week). This procedure obviously assumes that the preferences are heterogeneous in the population of divorced parents. The advantage of this technique is that no assumptions regarding the joint distribution or constancy of parental preferences are required. The main drawback is the fact that no provision is made for measurement errors or other types of data unreliability.

The values of the parameter "estimates" show that fathers are more selfish than mothers, that is they weigh their consumption more than their children's consumption and their time with them. On average, mothers value time spent with the child much more highly than do fathers. This results in large part produced by our assumption that mothers are endowed with all of the child's time initially. Since they start with high levels of time and "sell" little of it to the father, they must value it more highly than do fathers. Changes in the time endowment (i.e., giving the father a "right" to some of the time initially) increases mean $d_{m}$ and decreases mean $d_{f}$.

The model set out above can be used to determine the effect that different time arrangements and child support policies may have on divorce outcomes, assuming that the parents' preference parameters are fixed. We first analyze the effects of a time arrangement similar to joint custody, simulating the outcomes in terms of mother's available income and father's visits and expenditures under an endowment similar to joint custody. The data used come from the NLS-High School Class of 1972.

The results indicate that an endowment of equal time for both parents, (though beneficial to the children), leaves the mother worse off, by increasing the income disparity between the two parents. However, the increase in the father's direct expenditures to the child could partially compensate the mother's reduction in total consumption (by reducing her expenditures on the child) ii. Table 5 shows the results of the simulation in which the time endowment $\varepsilon$ from 1 (mother's custody) is fixed at 0.5 (joint custody) is equally split on mother consumption, visitation and 
voluntary expenditures. In joint custody mother's consumption is lower, but the proportion of time spend by the father with the children is higher as well as the direct expenditures

Using these estimates to simulating the outcomes in terms of mother's available income and father's visitations under $=0.5$, an initial endowment that we can claim gives both parents the same rights in terms of time to spend with the children (such as a joint custody agreement).

These results show that under an agreement in which both parents are entitled to the same amount of time, visitations are 34 percent of the total time and 47 percent respectively (using the preference parameters obtained under the two alternative assumptions). The income available to the mother (the sum of her income and the father's transfer) decreases when the time with the child is distributed equally among both parents. This means that in that case the mother cannot "sell" all the time to the father given that a portion of time is endowed to him. In both cases her available income is lower than the observed one. These results indicate that an endowment of equal time for both parents, though beneficial to the children, leaves the mother worse off, by increasing the income disparity between the two parents. This increase in direct expenditures to the child could partially compensate the mother's reduction in total consumption, allowing her to reduce her own expenditures on the child.

Table 5 Evaluation of custody arrangements

\begin{tabular}{|l|l|l|}
\hline & Mother custody & Joint Custody \\
\hline$c_{m}$ & 9,476 & 5,904 \\
\hline & $(6,640)$ & $(5,346)$ \\
\hline $\mathrm{V}$ & 0,126 & 0,473 \\
\hline & $(0,108)$ & $(0,084)$ \\
\hline$k_{f}$ & 1,125 & 1,478 \\
\hline & $(805)$ & $(1,171)$ \\
\hline
\end{tabular}

Source Del Boca Ribero 2001 ${ }^{\text {iii }}$

Therefore joint custody has a important role in determining the post-divorce distribution of incomes between parents. On the one hand, a more equal endowment of time with the children guarantees the father a positive amount of time with the child. On the other hand, joint custody allows the mother to continue to share her ex-husband's income and increases direct expenditures to the children. These results confirm previous descriptive findings (Del Boca and Ribero, 1998). 
Table 6 shows that a higher proportion of fathers with joint custody spend on their children directly than fathers in sole custody arrangements. They also are more involved in activities such as school events and homework ${ }^{\text {iv }}$.

\section{Table 6}

Custody and proportion of fathers who spend directly on the child.

\begin{tabular}{|l|l|l|}
\hline & Mother Custody & Joint custody \\
\hline Clothes & 0.25 & 0.65 \\
\hline Gifts & 0.35 & 0.45 \\
\hline Vacations & 0.22 & 0.56 \\
\hline Dental care & 0.23 & 0.56 \\
\hline Medical insurance & 0.37 & 0.67 \\
\hline Help with homework & 0.20 & 0.45 \\
\hline Attends school events & 0.22 & 0.44 \\
\hline
\end{tabular}

Source NLS Fifth Follow

If frequent visits allow the non custodian to observe and interact with the children and therefore control the outcomes of his expenditures, joint custody guarantees both parents the legal rights to an equal part in decision-making. In this case, in fact, neither parent can ignore the wishes of the other, for disregard of the parent's desires by the other may lead to retaliatory actions. If these points are valid, this would imply that the monitoring problem may be lessened under joint custody.

Another important aspect regards the public nature of household goods. When a child lives with one of his/her parents that parent must provide space appropriate for both adult and child, as well as a location, school, playground etc. The non-custodial parent does not need to take into account these characteristics. Under joint custody, the child shares public goods with both parents. More over in joint custody arrangements children must often have a double set of clothes and other important items. As Table 6 above shows fathers with joint custody spend more on items such as clothes for example.

The model and the empirical strategy described above can be used to simulate the effects of other child support policies. We can evaluate the effects that forcing different types of mandatory income transfers from the non-custodial parent have on visitation time and the mother's net income (Del Boca and Ribero 2001). For example, perfectly-enforced child support orders, such as those 
implemented in some states, can simply be viewed as an exogenous change in the parental income in favor of the mother. In such a situation, the model predicts less visitation by the father. The empirical exercise conducted below demonstrates that the size of this effect may be substantial.

We consider the impact of income redistribution from the father to the mother before the "market" for the child's time commences. We look at the impact of ordering fathers to transfer 17 percent of their income to their ex-wives. Compliance with these orders is assumed complete, possibly through the use of mandatory withholding.

Table 7 Evaluation of child support arrangements

\begin{tabular}{|l|l|l|}
\hline & $\begin{array}{l}\text { No Mandatory } \\
\text { Transfer }\end{array}$ & $\begin{array}{l}\text { Mandatory Transfer } \\
(17 \%)\end{array}$ \\
\hline$c_{m}$ & 9,476 & 11,941 \\
\hline & $(6,640)$ & $(7,176)$ \\
\hline$V$ & 0,126 & 0,085 \\
\hline$T$ & $(0,108)$ & $(0,078)$ \\
\hline & 2,321 & 4,786 \\
\hline$K f$ & $(2,028)$ & $(2,774)$ \\
\hline & 1,126 & 1.001 \\
\hline
\end{tabular}

Source : Del Boca Ribero 2001

As we can see from Table 7, the 17 percent mandatory transfer results in a gain in the average consumption of mothers of about 2500 dollars. The average transfer of fathers increases from 2321 before the orders are implemented, to 4786 after they are. Transfers under the program can be distinguished by whether they are voluntary or not. Since the average mandatory transfer under the program is about 2500 , there is a still sizeable voluntary transfer after the program is implemented. Finally, due to the reduced income of the fathers and the reduction in the marginal utility of consumption of the wealthier mothers, a lower amount of time with the child is purchased by the fathers. There is a substantial reduction in visitation time: about one-third.

Thus the mandatory transfer policy clearly benefits mothers who, on average, have higher consumption levels and spend more time with their child. While the child can be expected to also benefit from the increased consumption of the mother, with whom she spends most of her time, the increased concentration of time with one parent may have detrimental effects on child characteristics and outcomes not modeled here. 
Our results show that mandatory child support transfers from the father to the mother result in unambiguous welfare gains for the mother and losses for the father, as would be expected. A perhaps unintended side-effect of such a program is the large reduction in time spent with the child by the father. If the child's development is enhanced by balanced exposure to both parents, such a consequence may be of concern to policymakers interested in the long-term welfare implications of laws regulating divorce involving children. Our model implies that institutional agents can have important effects on the distribution of welfare within non-intact families through the endowment.

\section{Testing hypotheses and data issues.}

As our discussion has reported, in this area of analysis several behavioral models are now available, and they have very relevant policy implications. We need to establish however which modeling strategy is the most appropriate. In pursuing this goal, several problems are encountered. One problem is related to several biases which arise from the way respondents provide information on these issues. Another problem concerns the availability of information which enable us to test important hypotheses.

\section{Data issues and misreporting.}

The first problem is related to data issues involved in the way non-resident fathers respond to interviews. Three types of response biases can occur when a survey is conducted. The first one called non response bias arises when not all respondents cooperate with the interview and those who do not participate differ from those who do. The magnitude of this bias depends on the proportion of the sample who does not participate and how they differ from the participants The second one called item non response bias arises when the respondents skip a particular question. The third arises when participants misreport or deliberately provide incorrect response.

The reasons for items non response or survey non response bias have been analyzed in studies concerning divorced or separated households, mainly because the questions in these surveys involve emotionally sensitive issues, partly for other reasons. Non custodial fathers who pay only partially or not pay child support may fear legal punishment. This may induce them to skip the questions by declaring that they do not have a child or even do not answer the survey at all, or they misreport the information.

Shaeffer et al (1990) have computed estimates of non response bias for child support awards and payments and found that custodian mothers report accurately child support payments, 
while non custodian fathers over-report having paid child support. Rendall et al (1999) also shows that a large proportion of non-custodial fathers are in the survey but do not even acknowledge their paternal status and deny the existence of children.

Fig 2-4 show the difference in the distribution of child support orders and payment reported by custodians and non custodians. While child support orders are reported to be quite uniformally distributed by the custodians, are reported to be highly concentrated around values less than 400 a month by the non custodians. Similarly child support paid is 
Figure 2 Frequency of child support order (Custodians)

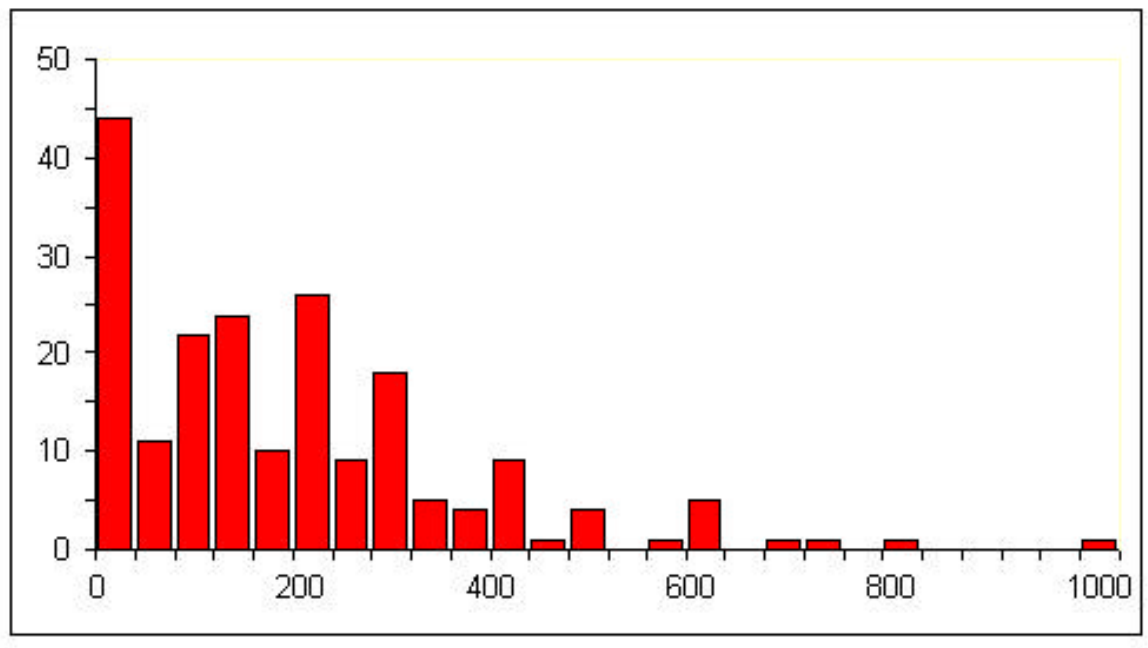

Figure 3 Frequency of Child support order (Non Custodian)

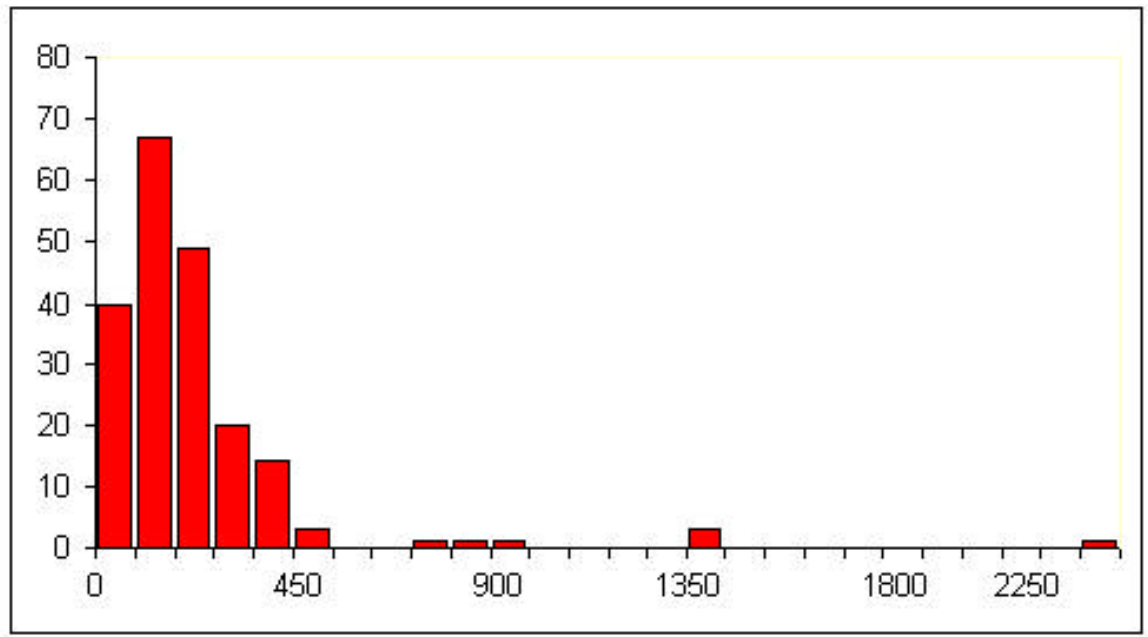


Figure 4 Frequency of Child support paid (custodians)

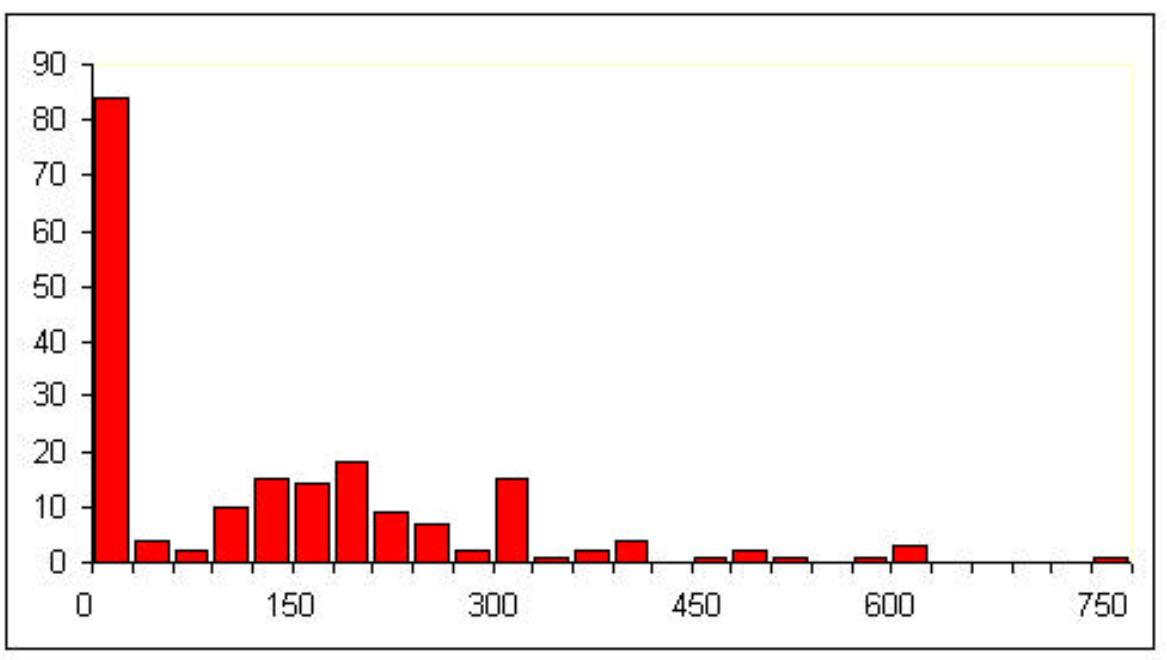

Figure 5 Frequency of Child support paid (non custodians)

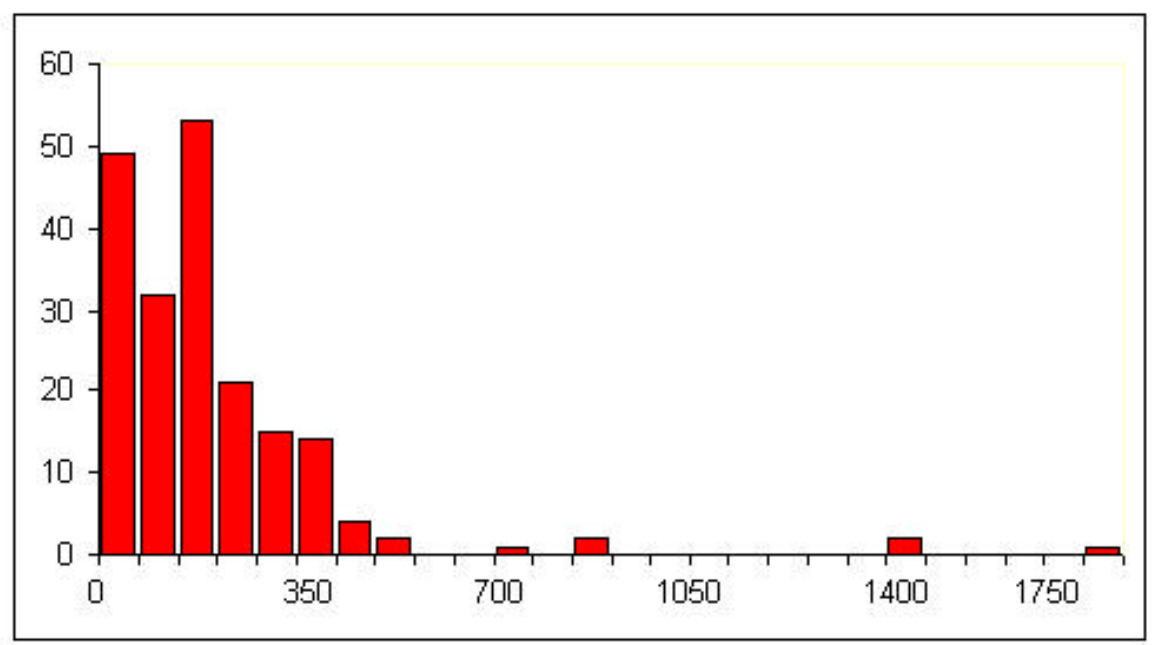

The issues of mis-reporting affect highly also the answers of visitations. As we have discussed above frequency of visitations between the non custodians fathers and his children are not less important than child support transfers.

Table 8 shows the different responses regarding the proportion of visits according to whether the mother or the father reports the information. 
Table 8 Visitations and Child support according to the parent who reports.

\begin{tabular}{|l|l|l|}
\hline & Mother reports & Father reports \\
\hline Visits once a week & 0.19 & 0.25 \\
\hline Visits twice a month & 0.27 & 0.28 \\
\hline Visits on vacations & 0.07 & 0.12 \\
\hline No visitations & 0.42 & 0.33 \\
\hline
\end{tabular}

Source NLS 5follow up NLS72-5FU.

When it is the mother who is interviewed, the proportion of frequent visitation (once a week or twice a month) is lower than when it is the father who reports. The opposite happens in case of the proportion of no visitations of non custodians which is higher when mothers report.

\section{Variables and hypotheses testing}

Besides the response bias, another problem is the actual lack of information on some important variables which would allow us to test different hypotheses concerning parents' behavior in non intact households.

In order to provide evidence that it is possible to differentiate between several behavioral models which explain interactions between divorced parents, we need to have information on the all vectors $\left(y_{f}, y_{m}, k_{f}, k_{m}, t, s, e\right)$ that report parents' incomes, parents' expenditures on the child, the child support transfers, the child support orders, and the time endowments to each parent. As we discussed earlier, behavioral models analyzing post-divorce welfare have made different assumptions regarding the resource allocation, the manner in which decisions are made in the family and way the institutional agent can intervene.

Consider for example the different ways in which expenditures on the child are modeled in the research we have presented in the previous section.

\begin{tabular}{|l|l|l|}
\hline & Model & Author \\
\hline$k\left(=k_{m}\right)$ & $\delta_{l} y_{f}+\delta_{2 f} y_{m}+\delta_{3} t$ & Flinn (2000) when $\mathrm{t}=\mathrm{s}$ \\
\hline$k\left(=k_{m}\right)$ & $\delta_{l}\left(y_{m}+t\right)$ & Del Boca and Flinn (1995) \\
\hline$k\left(=k_{f}, k_{m}\right)$ & $g\left(y_{m}, y_{f}, \varepsilon\right)$ & Del Boca and Ribero (1999) \\
\hline
\end{tabular}


We can summarize two important, testable differences among the various models we have described and discussed above. The first difference concerns the allocation of resources by the parents to the public good (the child). As is summarized in the table above it is assumed in both Del Boca and Flinn (1995) and in Flinn (2000) that only the mother (the custodian) can make [significant] expenditures on the child, that is $\left(k=k_{m}\right)$, while in Del Boca and Ribero (1999) it is assumed that both parents can make direct expenditures on the child ( $\left.k=k_{f}, k_{m}\right)$

Another important difference concerns the mode of decision making. While Del Boca Flinn (1995) and Del Boca and Ribero (1999) assume that parents behave non-cooperatively after divorce, in Flinn (2000) parents may cooperate or not [cooperative behavior occurs whenever $t=s$, in other words there is exact compliance with the child support order by the non-custodial father].

Only if we have information on the vector $\left(y_{f}, y_{m}, k_{f}, k_{m}, t\right)$, we can differentiate between the models. If data on expenditure on the children, $k$, is available and shows that a substantial number of fathers spend directly on the children (such as in Del Boca and Ribero) some doubts might be cast on the assumptions made in the other papers (Del Boca and Flinn 1995, and Flinn 2000). If we find that $d_{1}, d_{2}$ and $d_{3}$ are not the same, we would reject the assumptions made in Del Boca and Flinn, in favor of Flinn. This would imply that parents can behave cooperatively and therefore policies could be directed towardsn creating incentives for this behavior.

Unfortunately, the data sets available for the study of children's welfare after divorce have many limitations: for example, the data sets available are administrative data which contain information about the characteristics of the parents as well as child support but no information about expenditure on children, which in contrast are available in the Consumer Expenditure survey. Other data sets more specifically on divorced parents are not representative.

Given these limitations, several problems exist in distinguishing between models in designing appropriate policies. This would explain why child-support reform policies have so far had relatively limited impact on children's welfare and should encourage greater efforts being made to improve the quality of the data regarding separated households and their children.

\section{Conclusions}

In this paper we have discussed a field of economic research that examines the role of institutions in the determination of the post-divorce welfare of parents and children. Institutional agents intervene in divorced households mainly out of concern for the negative effect of separation 
on parents' motivation to spend resources on the child. The economic models which explicitly consider the role of institutions combining bargaining theory and microeconomic analysis make it possible to perform important policy experiments which could hopefully provide some guidance in the formulation of efficient and equitable divorce laws. In fact they can be used to simulate and compare alternative child support policies. The effects of changes of different changes in post divorce arrangements on the welfare of children, mothers and fathers (child support orders, costs of non compliance, changes in the enforcement power of the judges and changes in custody arrangements) can also be evaluated.

We have provided several examples of how the results can be quite relevant for policy issues (Del Boca and Flinn 1995). The estimates of the preferences of the institutional agents show that non-custodial fathers are given preferential treatment relative to mothers and children. This means that child support orders are low not only because compliance becomes less likely as the order increases but because of the relatively low valuation of the expected welfare of custodial mothers and children by institutional agents.

Another result concerns the effect of an increase in the penalty associated with noncompliance: the expected transfers increase and the custodial parents and children experience an increase in their welfare. However, taking into account judges' preferences, when the probability of complying increases, the order decreases. Since the judges give substantial weight to fathers' welfare, the institutional agents reduce the order, offsetting the increase in expected transfers.

Another policy experiment concerns perfect enforcement (Flinn 2000), which was found to have little effect on children's expected welfare. When transfers are guaranteed by the state, the mother has no incentive to engage in cooperative behavior so as to induce the father to make the transfer to her. Therefore perfect enforcement has a cost, which is the lack of opportunity to lead parents to cooperative behavior (with increased spending on the public good, the child).

When we consider the effect on the distribution of time with the child (Del Boca and Ribero 1999, 2001) the results indicate that an endowment of equal time for both parents leaves the mother worse off by increasing the income disparity between the two parents. However, the increase in the father's direct expenditures to the child could partially compensate the mother's reduction in total consumption (by reducing her expenditures on the child). Therefore joint custody has an important role in determining the post-divorce distribution of incomes between parents.

Finally the institution of mandatory child support transfers from the father to the mother has positive effect on transfers but negative effects on visitations. A side-effect of such program is in fact a reduction in time spent with the child by the father. 
All these results contain aspects relevant to policy-makers interested in the long-term welfare implications of laws regulating divorce involving children. The institutional agent plays an important role in determining the distribution of welfare and the redistribution of monetary resources and time.

\section{Bibliography}

Browning, Martin.(1992) Children and Household Economic Behavior. Journal of Economic Literature 30: 1434-1477.

Beller, A., and Graham J. (1993). Small Change: The Economics of Child Support. New Haven: Yale University Press.

Bradshaw, J., Ditch, J., Holmes, H., Whiteford, P., (1997). Support for the Children: A Comparison of Arrangements for fifteen Countries. London: Department of Social Security.

Chiappori P.A (1992) Collective Labor Supply and welfare Journal of Political Economy 100: 437-467.

Cooter, R., Marks, S., Mnookin, Robert.(1982) Bargaining in the Shadow of the Law: A Testable Model of Strategic Behavior. Journal of Legal Studies 11: 225-251.

Corden A. Making Child Maintenance Change Family Policy Studies Centre London 1999.

Del Boca, D. (1996) An Evaluation of Child Support Reforms. Labour 14:104-126.

Del Boca, D., Flinn, C. (1994a) The Determination of Welfare in Non-intact Families. In The Measurement of Household Welfare, eds. Blundell, R., Preston, I. and Walker, I. Cambridge: Cambridge University Press, 111-139.

Del Boca, D., Flinn, C. (1994b) Expenditure Decisions of Divorced Mothers and Income Composition. Journal of Human Resources 29: 742-761. 
Del Boca, D., Flinn, C. (1995). Rationalizing Child Support Decisions. American Economic Review 85: 1261-1282.

Del Boca, D. Ribero, R. (1998) Transfers in Non intact Households. Structural Changes and Economic Dynamics 9: 469-479.

Del Boca D. (1998) Intrahousehold Distribution in Families with Children,' in The Economics of the Family (I. Parsson and C. Jonung, eds.). London: Routledge.

Del Boca, D. and Ribero, R. (1999) Visitations and Transfers after Divorce. C. V. Starr Center Research Report No. RR-99-8 New York University November 1999.

Del Boca, D. and Ribero, R.(2001) Evaluation of Child Support Policies. American Economic Review vol.91: 130-135.

Duncan, G. and Hoffman, S. (1985) A Reconsideration of the Economic Consequences of Marital Dissolution.” Demography 22: 485-497.

Ermisch J.F. and Francesconi M. (2001) Family Structure and Children Achievements Journal of Population Economics, 14 : 249-270

Elster, J. (1989) Solomonic Judgements: Studies in Rationality. Cambridge: Cambridge University Press.

Flinn, C. J. (2000). “Modes of Interaction Between Divorced Parents.” International Economic Review, 41: 545-578.

Garfinkel, I., and Klawitter, M.(1990) The Effect of Routine Income Withholding on Child Support Collections." Journal of Policy Analysis and Management 9:155-177. 
Garfinkel, I, and Melli, M. (1990) The Use of Normative Standards in Family Law Decisions:

Developing Mathematical Standards for Child Support.” Family Law Quarterly 24: 157-178.

Garfinkel, I. and Oellerich, D. (1989) Noncustodial Fathers' Ability to Pay Child Support.

Demography 26: 219-233.

Goode, W., (1993) World changes in divorce patterns Yale University Press New Haven CT .

Haveman R. and Wolfe B. (1994) Succeeding Generations Russel Sage New York.

Hernandez P. M. A. Beller, Graham J. ( 1996) The Child Support Enforcement Amendements of 1984 and Educational attainment of Young Adults in the US Labour 10:537-559.

Hill Ms, Yeung W, J.J. Duncan G.J "Childhood family Structure and Young Adults Behaviour" Journal of Population Economics 2001, 14 : 271-300

Janti M. Danziger S. (1994) Child poverty in Sweden and United States. Ind. labor Relations Review 48: 48-63.

Lazear, E. and Michael R. ( 1988) Allocation of Income within the Household. Chicago: University of Chicago Press,

Maccoby, E., and Mnookin, R. Dividing the Child: Social and Legal Dilemmas of Custody.

Cambridge, MA.: Harvard University Press, 1992.

Mnookin, R. (1985) In the Interest of Children: Advocacy, Law Reform, and Public Policy. New York: W.H. Freeman, 1985.

Mnookin, Robert and Weisberg, D. K. (1988) Child, Family, and State: Problems and Materials on Children and the Law. Boston: Little, Brown and Company, 1988.

Mnookin, R. and Kornhauser, L. Bargaining in the Shadow of the Law: The Case of Divorce." Yale Law Journal 88 (April 1979): 950-997. 
Pearson, J. and Thoennes, N. (1988) Supporting Children after Divorce: The Influence of Custody on Support Levels and Payments. Family Law Quarterly 22: 319-339.

Rendall M. Clarke L. Peters E. Ranjit N. Verropalou G. Incomplete reporting of Male Fertility in Us and Britain Demography (1999) 36 (11) 135-144.

Ribero R. (1994) Post divorce family Ties Unpublished Ph. D. Dissertation New York University.

Sunstein, C. (1986) Legal Interference with Private Preferences. University of Chicago Law Review 53: $1129-1174$.

Schaeffer N. C., Seltzer Judith, Kawitter Marieka "Estimating Non response and Response Bias" Sociological Methods and Research 1991 vol 20, n. 1:30-59.

Schultz T.P (1990) Testing the neoclassical model of family labor supply and fertility Journal of Human Resources 25:599-634.

Weiss, R. (1984) The Impact of Marital Dissolution on Income and Consumption in Single-Parent Households." Journal of Marriage and the Family 46: 115-129.

Weiss, Y. and Willis, R. (1985)“Children as Collective Goods and Divorce Settlements. Journal of Labor Economics 3: 268-292.

Weiss, Y., Willis, R. (1989) An Economic Analysis of Divorce Settlements. Economics Research Center NORC Working Paper ERC89-5.

Weiss, Y., Willis, R.. (1993) Transfers among Divorced Couples: Evidence and Interpretation.” Journal of Labor Economics 11: 629-679.

Weitzman, L. (1985) The Divorce Revolution: The Unexpected Social and Economic Consequences for Women and Children. New York: The Free Press. 
Williams, R. (1994) Overview of Child Support Guidelines in the US. in Child Support Guidelines: the next generation. (ed. Margaret Campbell Haynes) U. S Department of Health and Human Services.

White K. and Stone R. T. (1976) A Study of Alimony and Child Support Rulings with some recommendations Family Law Quarterly 10 (83).

Yee, L. (1979) What Happens in Child Support Cases? Denver Law Journal 57: 21-68.

\footnotetext{
${ }^{\mathrm{i}}$ The father remarriage has a negative effect also on child support transfers, while the mother remarriage has no effect (Del Boca and Ribero 1998).

ii The data used are from the National Longitudinal Survey Fifth Follow up High School Class of 1972 (NLS72-5FU).

iii The information concerning mother's direct expenditures is not available.

${ }^{\text {iv }}$ Parents with joint custody arrangements have higher income, higher education and are less likely to be remarried than parents in sole custody arrangements.
} 


\section{IZA Discussion Papers}

\begin{tabular}{|c|c|c|c|c|}
\hline No. & Author(s) & Title & Area & Date \\
\hline 413 & $\begin{array}{l}\text { H. Bonin } \\
\text { R. Euwals }\end{array}$ & $\begin{array}{l}\text { Participation Behavior of East German Women } \\
\text { after German Unification }\end{array}$ & 1 & $12 / 01$ \\
\hline 414 & $\begin{array}{l}\text { A. Frederiksen } \\
\text { N. Westergaard- } \\
\text { Nielsen }\end{array}$ & Where Did They Go? & 1 & $01 / 02$ \\
\hline 415 & $\begin{array}{l}\text { M. Bertrand } \\
\text { F. Kramarz }\end{array}$ & $\begin{array}{l}\text { Does Entry Regulation Hinder Job Creation? } \\
\text { Evidence from the French Retail Industry }\end{array}$ & 6 & $01 / 02$ \\
\hline 416 & $\begin{array}{l}\text { B. Crépon } \\
\text { F. Kramarz }\end{array}$ & $\begin{array}{l}\text { Employed } 40 \text { Hours or Not-Employed 39: } \\
\text { Lessons from the } 1982 \text { Mandatory Reduction of } \\
\text { the Workweek }\end{array}$ & 6 & $01 / 02$ \\
\hline 417 & J. Wagner & $\begin{array}{l}\text { Taking a Second Chance: } \\
\text { Entrepreneurial Restarters in Germany }\end{array}$ & 1 & $01 / 02$ \\
\hline 418 & $\begin{array}{l}\text { M. Frölich } \\
\text { P. A. Puhani }\end{array}$ & $\begin{array}{l}\text { Immigration and Heterogeneous Labor in } \\
\text { Western Germany: A Labor Market } \\
\text { Classification Based on Nonparametric } \\
\text { Estimation }\end{array}$ & 2 & $01 / 02$ \\
\hline 419 & $\begin{array}{l}\text { P. Frijters } \\
\text { J. P. Haisken-DeNew } \\
\text { M. A. Shields }\end{array}$ & $\begin{array}{l}\text { The Value of Reunification in Germany: } \\
\text { An Analysis of Changes in Life Satisfaction }\end{array}$ & 6 & $01 / 02$ \\
\hline 420 & $\begin{array}{l}\text { Å. Rosén } \\
\text { E. Wasmer }\end{array}$ & $\begin{array}{l}\text { Higher Education Levels, Firms' Outside Options } \\
\text { and the Wage Structure }\end{array}$ & 1 & $01 / 02$ \\
\hline 421 & P. Manzini & Divide et Impera: Negotiating with a Stakeholder & 6 & $02 / 02$ \\
\hline 422 & $\begin{array}{l}\text { J. T. Addison } \\
\text { L. Bellmann } \\
\text { C. Schnabel } \\
\text { J. Wagner }\end{array}$ & $\begin{array}{l}\text { The Long Awaited Reform of the German Works } \\
\text { Constitution Act }\end{array}$ & 6 & $02 / 02$ \\
\hline 423 & $\begin{array}{l}\text { E. Feess } \\
\text { G. Muehlheusser }\end{array}$ & Transfer Fee Regulations in European Football & 1 & $02 / 02$ \\
\hline 424 & $\begin{array}{l}\text { F. Büchel } \\
\text { M. van Ham }\end{array}$ & $\begin{array}{l}\text { Overeducation, Regional Labour Markets and } \\
\text { Spatial Flexibility }\end{array}$ & 3 & $02 / 02$ \\
\hline 425 & F. Büchel & $\begin{array}{l}\text { Successful Apprenticeship-to-Work Transitions: } \\
\text { On the Long-Term Change in Significance of the } \\
\text { German School-Leaving Certificate }\end{array}$ & 3 & $02 / 02$ \\
\hline 426 & $\begin{array}{l}\text { J. Hartog } \\
\text { W. P. M. Vijverberg }\end{array}$ & $\begin{array}{l}\text { Do Wages Really Compensate for Risk Aversion } \\
\text { and Skewness Affection? }\end{array}$ & 5 & $02 / 02$ \\
\hline 427 & D. Del Boca & $\begin{array}{l}\text { The Effect of Child Care and Part Time } \\
\text { Opportunities on Participation and Fertility } \\
\text { Decisions in Italy }\end{array}$ & 6 & $02 / 02$ \\
\hline 428 & D. Del Boca & $\begin{array}{l}\text { Mothers, Fathers and Children after Divorce: } \\
\text { The Role of Institutions }\end{array}$ & 6 & $02 / 02$ \\
\hline
\end{tabular}

